\title{
The First Record of the Spawning Run of Masu Salmon Oncorhynchus masou Introduced into the Patagonian Lake General Carrera, Southern Chile*1
}

\author{
Mitsuo Sakai, ${ }^{* 2,3}$ Eduardo Estay, ${ }^{* 4}$ Akio Nakazawa, ${ }^{* 2,5}$ \\ Naoto Okumoto, ${ }^{* 0}$ and Aliaky Nagasawa ${ }^{* 2,3}$
}

(Received April 10, 1992)

\begin{abstract}
Masu salmon fry Oncorhynchus masou of two different origins, Chilean stock (MC) of $7.0 \mathrm{~g}$ size parr and Japanese stock (MJ) of $4.9 \mathrm{~g}$ size parr, were released in February 1987 and in October 1987, respectively, into a tributary of Lake General Carrera in Chilean Patagonia. The spawning run of the salmon ( 299 females and 276 males) was observed in the river from March to April 1989. The sex ratio (males per female) was regarded as nearly 1.0, and this suggested that river-resident precocious males were very scarce in the river. Mean fork lengths and weights of spawners were $56.3 \mathrm{~cm}$ and $1,715 \mathrm{~g}$, respectively. The rate of return was estimated as $1.07 \%$ for $\mathrm{MC}$ and $0.95 \%$ for MJ. No difference between either rate was observed though they were released at different sizes and times. Eyed-stage eggs and alevins were found in the river after the spawning season. These indicated that there is a high possibility of population establishment in the lake by the small parr release of masu salmon.
\end{abstract}

It takes many years to establish a self-supporting salmon population introduced into a new environment. ${ }^{1)}$ On the Chilean coast, transplantation or introduction of some Pacific salmon species Oncorhynchus spp. has also been attempted since early this century. ${ }^{2-4)} 85,000$ masu salmon fry $O$. masou were released into a tributary of the Simpson river system in Chilean Patagonia for the first time in 1973. ${ }^{\mathrm{s}}$ ) Though nearly 1 million salmon parr and smolt were transplanted from Japan to the region up to 1986 , no spawning run for the establishment of sea-run stock has been observed. ${ }^{\text {) }}$

In 1987 we started an introduction program of the salmon using another tactic, introducing salmon into Lake General Carrera (Baker River System) for establishment of a lake-dwelling population.? In March 1989, we observed the first spawning run of the salmon in a tributary of the lake which we stocked with the salmon parr in 1987.*7 The object of this study is to describe the masu salmon's habit of returning to the release site, particularly the rate of return and growth in the lake. We aslo examined the possibility of the stock establishment.

\section{Materials and Methods}

\section{Study Site}

Lake General Carrera is a large $\left(1,883 \mathrm{~km}^{2}\right)$ lake located in Patagonia. The Chilean section is known as "Lago General Carrera $\left(977 \mathrm{~km}^{2}\right)$ " and the Argentine section as "Lago Buenos Aires $\left(906 \mathrm{~km}^{2}\right)$ " (Fig. 1). The lake elevation is about $200 \mathrm{~m}$ and the lake water flows down through the River Baker, $150 \mathrm{~km}$ in length, to the Pacific Ocean. The river has some cataracts, and so it prevents anadromous fish from upstream migration to the lake. The transparency of the lake is high, over $8 \mathrm{~m}$ in depth, off the lake shore. In Chilean territory there are many rivers and streams originating from Andes mountain glaciers. On the other hand, in Argentine territory few rivers flow into the lake because of the pampas climate.

*1 Partly presented at the annual meeting of the Japan. Soc. of Sci. Fish., Tokyo, 1990.

*2 Dr. Shiraishi's Hatchery of JICA-Japan International Cooperation Agrency, Coyhaique, Chile.

*3 Present Address: Centro de Ecologia Aplicada del Neuquen (CEAN-JICA), Junin de Los Andes, Prov. Neuquen, Argentina.

*4 Dr. Shiraishi's Hatchery of IFOP-Instituto de Fomento Pesquero, Coyhaique, Chile.

*5 Overseas Fishery Cooperation Foundation, Akasaka, Minato, Tokyo, Japan.

* Nikko Branch, National Institute of Aquaculture, Chugushi, Nikko, Tochigi, 326-16 Japan.

*7 M. Sakai and E. Estay: unpublished. 


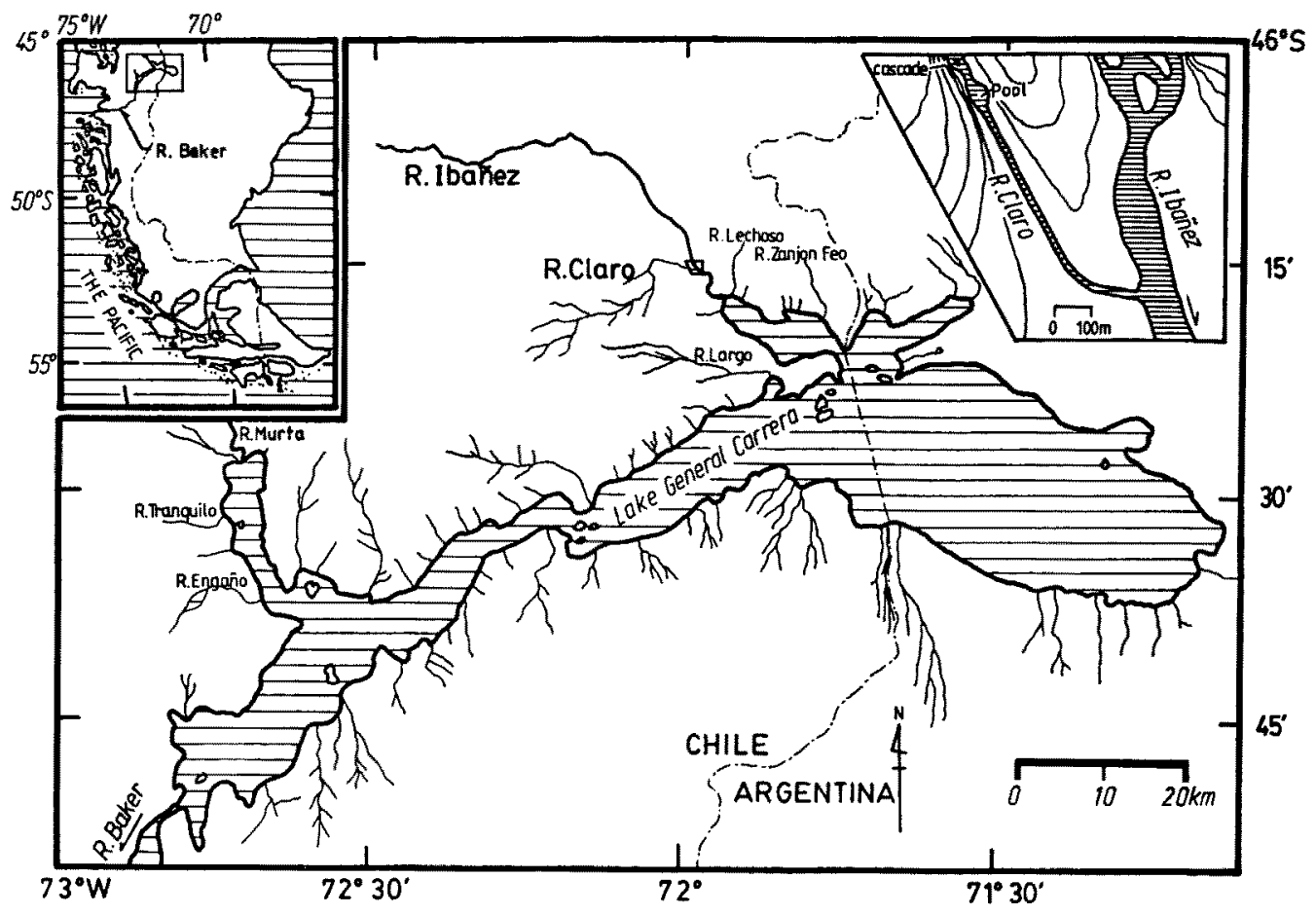

Fig. 1. Map showing Lake General Carrera and the river systems in Patagonia. The River Claro, stocked with masu salmon parr, is located in the northern part of the lake and is a tributary of the R. Ibañez.

Main river systems flowing into the lake are the River Ibañez and the River Murta in Chilean territory.

Freshwater fish fauna in the lake system is poor, only two native fish (pejerrey argentino Odonthestes bonariensis, and perca trucha Percicththys trucha) and two introduced trout (Oncorhynchus mykiss and Salmo trutta) have been recorded in the lake and its tributaries. ${ }^{* 8}$

For the first transplantation of the salmon to the lake system, we selected the River Claro, a tributary of the Ibañez river system. The water is usually very clear and relatively poor in benthic

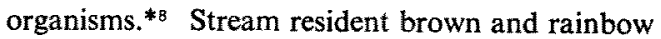
trout exist sympatrically, but the abundance is very low. In the River Claro there is a waterfall of over $3 \mathrm{~m}$ in height, which prevents fish from upstream migration, at a distance of $700 \mathrm{~m}$ from the junction of the River Ibañez. $A$ basin and broad pool, about $1,000 \mathrm{~m}^{2}$ in area and 0.5 to $1.3 \mathrm{~m}$ in depth, is formed under the waterfall (Fig. 1). From early May to July, spawners of lake-dwelling brown trout occupy the whole pool as a spawning ground. Few rainbow trout spawners have been observed in the pool.

\section{Released Fry}

Two different sources of fry stock were prepared for release in the River Claro. One was from masu salmon wild stock of Japanese origin, shipped by air in eyed-stage eggs (fertilized in 1986) from Mori (Hokkaido) in Japan; this was named "MJ-86". The other one was from Chilean stock as a second generation of Japanese stock, obtained from the "MJ-83" spawners in 1986 and bred in Dr. Shiraishi's Hatchery in Chile; this was named "MC-86". MC-86 fry swam up in early September 1986 just after the winter season, while MJ-86 fry swam up in January 1987. There was a difference of five months in swim-up time between MC-86 and MJ-86. We treated the masu salmon age as the number of winter marks on the scales. Generally, scale formation in salmon occurs on about $3 \mathrm{~cm} \mathrm{fry?}$ after swimming up, and the MC-86 fry did not have the 1986 winter mark on their scales. For

*5 M. Sakai and E. Estay: unpublished. 
Table 1. Release of masu salmon into the $\mathbf{R}$. Claro of General Carrera lake system in 1987. BW and FL indicate mean body weight (g) and fork length $(\mathrm{cm})$ of released fish

\begin{tabular}{ccccc}
\hline $\begin{array}{c}\text { Stock } \\
\text { group }\end{array}$ & Date & $\begin{array}{c}\text { BW } \\
(\mathrm{g})\end{array}$ & $\begin{array}{c}\text { FL } \\
(\mathrm{cm})\end{array}$ & $\begin{array}{c}\text { No. } \\
\text { released }\end{array}$ \\
\hline MC-86*1 & 10 Feb. & 7.0 & 9.1 & 32,000 \\
MJ-86*2 & 26 Oct. & 4.9 & 8.0 & 24,500 \\
\hline$* 1$ & & & & \\
\hline * 1 $^{+}$parr. & & & & \\
\hline
\end{tabular}

convenience's sake, we took the winter of 1987 to be $0^{+}$for fry from both sources.

We released 32,000 parr of $\mathrm{MC}-86\left(0^{+}\right)$on 10 February 1987 and 24,500 parr of $\mathrm{MJ}-86\left(1^{+}\right)$ on 26 October 1987 into the River Claro (Table 1).

\section{Capture of Spawners, and Analysis}

Several types of fishing gear, e.g. gill nets, cast nets, and a seine, were used to capture all returning masu salmon in the River Claro from $16 \mathrm{March}$ to 13 April 1989. Two gill nets, $90 \mathrm{~mm}$ in stretched mesh size, $30 \mathrm{~m}$ in length, and $2 \mathrm{~m}$ in height, were set in the rapids for the spawners migrating upstream. Fish caught by the nets were checked every day. Two cast nets, $1.5 \mathrm{~cm}$ and $2.0 \mathrm{~cm}$ in stretched mesh size, were operated to capture stream resident salmon and trout. We used the seine, $60 \mathrm{~mm}$ in stretched mesh size, $50 \mathrm{~m}$ in length, and $3 \mathrm{~m}$ in height, for "roundup catch" of the spawners gathering in the pool every week from $18 \mathrm{March}$ to 4 April. In addition to this capture survey, we asked local fishermen for salmon catch information. We carried out investigations of some other rivers around the Ibañez and Murta river systems during the spawning season.

We measured the fork length and body weight of all spawners captured. The spawners were divided according to sex. We examined the daily percentage of spawned females. Over $25 \%$ of the spawners were chosen at random from each sex group for scale analysis. Scales of the spawners were analyzed according to the standard method $^{8)}$ with a profile projector. The stock group (MC-86 or MJ-86) of the sample was determined by discrimination value on circuli number from focus to the first winter mark; the circuli number on Chilean stock fish is more than 15 while that on Japanese stock is 13 or less (Fig. 2). ${ }^{\text {) }}$

The group proportion of the sample (the percentage of each stock group, MC-86 or MJ-86)

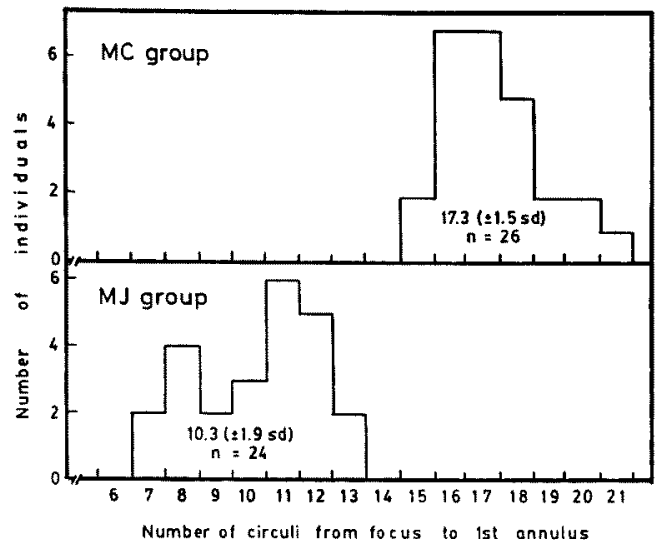

Fig. 2. Frequency distribution of circuli numbers from the focus to the first winter mark on MC and $\mathrm{MJ}$ groups. Mean numbers and standard deviation (sd) are shown.

was calculated. On the assumption that the sample was representative of all the spawners caught in the river, the stock numbers of all the returning fish were extrapolated from the stock proportion of the sample spawners.

The rate of return $(R)$ of 3 year-old spawners $\left(2^{+}\right)$was calculated for each stock (MC-86 and MJ-86) as follows:

$$
R(\%)=N_{\mathrm{s}} / N_{\mathrm{r}} \times 100
$$

where $N_{\mathrm{r}}$ indicates the number of salmon fry released and $N_{\mathrm{a}}$ indicates the number of spawners returned to the River Claro only in 1989.

Winter marks on masu salmon scales in southern Chile are formed in early September (spring). We estimated the fork length in each overwintering period (or early September) by the following back-calculation formula for the salmon: ${ }^{\text {) }}$

$$
\begin{gathered}
F L=3.725 S R^{2}+13.323 S R+3.047 \\
(n=41, R=0.989)
\end{gathered}
$$

where $F L$ and $S R$ indicate fork length $(\mathrm{cm})$ and scale radius $(\mathrm{mm})$, respectively. We chose some fish which only possessed definite winter marks on their scales for the length estimation, in order to avoid errors in estimating the length in the overwintering period by using scales with unclear winter marks.

We observed the development of embryos in the spawning grounds from March to September 1989. Water current velocities on redd sites were measured with a current meter (Tamaya \& Co. Ltd.). The water temperature $\left({ }^{\circ} \mathrm{C}\right)$ of the river was monitored with a thermograph (Ryan, 


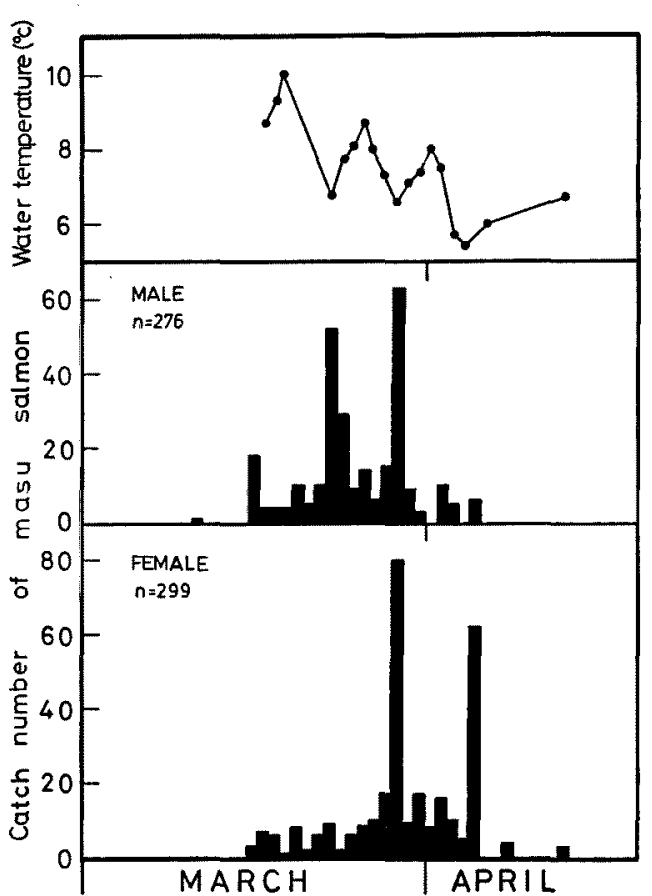

Fig. 3. Daily catch of masu salmon spawners from March to April 1989 in the R. Claro, and fluctuation of the water temperature.

Model J) from March to September 1989. We examined monthly changes in the water level at the River Claro pool through data from fluviometric stations of the General Direction of Waters. Dissolved oxygen (DO ppm) and $\mathrm{pH}$ were also measured in the spawning season. We examined river benthos with a Surber-type stream bottom sampler (25 cm square) on 12 May 1989.

\section{Results}

Capture of Masu Salmon Spawners

On 16 March 1989 we succeeded in the first capture of masu salmon returning to the River
Claro by gill net. We obtained information that a local fisherman had caught a male salmon in the river before our first catch. The spawning run in the River Claro was observed for over one month from mid-March to mid-April (Fig. 3). More male fish than female were caught from midMarch to late March, but after late March the female spawner catch increased. Capture of salmon coincided with a decrease in water temperature from $10^{\circ} \mathrm{C}$ to $6^{\circ} \mathrm{C}$.

The total catch number reached 575 spawners (299 females and 276 males) by mid-April. There was no statistical difference between the number of females and that of males (by $G$-test, $G=$ $0.9202<\chi_{0.01}^{2}$ ). The sex ratio (males per female) was calculated at 0.923 , and we regarded the ratio as 1.0. We could not find masu salmon spawners in neighboring streams (R. Largo, R. Lechoso, or R. Zanjon Feo) or in other river systems ( $\mathbf{R}$. Murta, R. Tranquilo, or R. Engano), and we caught only rainbow and brown trout there.

All the spawners were over $40 \mathrm{~cm}$ in fork length and showed the typical nuptial color of masu salmon; the body was bright pink with dark vertical bars, while the pectoral, pelvic, and anal fins and the head were black. All male spawaners had hooked and black snouts. Some brown trout parr were caught by cast nets, but small-sized "yamame type" (river-resident parr) were neither observed nor caught in the spawning grounds.

\section{Rate of Return}

To discriminate between $\mathrm{MC}-86$ and $\mathrm{MJ}-86$ stock, we examined 155 individuals ( 58 female and 97 male) by scale analysis. This sample size was $27 \%$ of the total run. The proportions $(\%)$ of MC-86 and MJ-86 of the sample spawners were estimated at $59.5 \%$ and $40.5 \%$, respectively (Table 2). There was no significant difference in the stock proportion between returned spawners

Table 2. Stock proportion (SP)*1 of spawners and the rate of return estimated for each stock group of the spawners in the R. Claro

\begin{tabular}{|c|c|c|c|c|c|c|}
\hline \multirow{2}{*}{$\begin{array}{l}\text { Stock } \\
\text { group }\end{array}$} & \multicolumn{2}{|c|}{ Released fry } & \multicolumn{2}{|c|}{ Sample spawners } & \multirow{2}{*}{$\begin{array}{l}\text { Extrapolated } \\
\text { No. Spawners }\end{array}$} & \multirow{2}{*}{$\begin{array}{l}\text { Rate of } \\
\text { return (\%) }\end{array}$} \\
\hline & No. & $\operatorname{SP}(\%)$ & No. & $\mathrm{SP}(\%)$ & & \\
\hline MC-86 & 32,000 & 56.6 & $92 * 2$ & 59.5 & 342 & 1.07 \\
\hline MJ-86 & 24,500 & 43.4 & $63^{* 3}$ & 40.5 & 233 & 0.95 \\
\hline Total & 56,500 & 100.0 & 155 & 100.0 & 575 & Mean 1.02 \\
\hline $\begin{array}{ll}* 1 & \text { Percen } \\
* 2 & 35 \mathrm{fem}\end{array}$ & $\begin{array}{l}\text { ach stock g } \\
57 \text { males. }\end{array}$ & & & & & \\
\hline
\end{tabular}




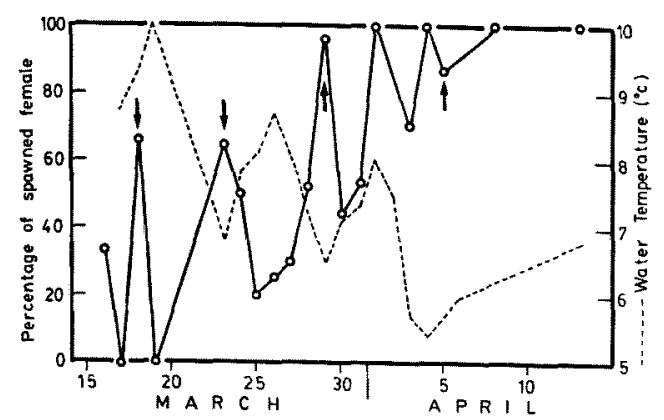

Fig. 4. Daily fluctuation of percentage of spawned females (spawned female numbers per total female numbers) caught in the $R$. Claro, and fluctuation of the water temperature. Arrow indicates "roundup catch" with a seine.

and released fry ( $\chi^{2}$-test, $p>0.7$ ). We extrapolated the return number of each stock from the stock proportion of the sample spawners and obtained the number of the spawners in each stock group. The rate of return in each stock group gained about $1 \%$ (Table 2 ).

\section{Spawning}

The percentage of spawned females increased with daily fluctuations from mid-March and reached over $80 \%$ in early April (Fig. 4). A high percentage of spawned females was recorded by the weekly "roundup catch" with a seine; over $60 \%$ of females caught with the seine every week had already spawned. Some spawners captured in the River Claro were still immature but they matured over a week in a preservation cage set in the river.

We observed many salmon spawning in the pool and the rapids throughout the investigation, and found many redds and clutches. Current velocities over the redds averaged $46.7 \mathrm{~cm} / \mathrm{sec}$ $(\mathrm{n}=7, \mathrm{SD}=17.3)$. On 12 May 1989 we found eyed-stage embryos of the salmon deposited in the redds with some fertilized eggs of brown trout (water temperature $5.7^{\circ} \mathrm{C}, \mathrm{DO} 12.3 \mathrm{ppm}$, $\mathrm{pH}$ 7.2). Eggs of each species can be distinguished by their size. The salmon eggs were obviously larger than the trout eggs; the former egg diameter averaged $6.71 \mathrm{~mm}(\mathrm{SD}=0.24 \mathrm{~mm}, \mathrm{n}=10)$ while the latter averaged $5.38 \mathrm{~mm} \quad(\mathrm{SD}=0.12 \mathrm{~mm}$, $n=5$ ).

Benthic insects in the spawning area were not abundant in mid-May 1989 . The biomass was low ( 0.288 wet weight $\left.\mathrm{g} / \mathrm{m}^{2}, \mathrm{n}=5, \mathrm{SD}=0.461\right)$. On 25 July we collected a few alevins in redds (water temperature $4.0^{\circ} \mathrm{C}$ ), but the abundance was very low. On 14 September, though we carried out a capture survey for fry using a cast net, we could not find any free-swimming fry in the river (water temperature $6.8^{\circ} \mathrm{C}$ ).

\section{Growth}

The mean fork lengths of spawners according to MC-86 and MJ-86 groups from the 155 individuals by scale analysis were $57.2 \mathrm{~cm}$ and $55.2 \mathrm{~cm}$, respectively (Table 3 ). The mean weight of the MC-86 and MJ-86 groups were 1,777 and $1,592 \mathrm{~g}$, respectively (Table 3 ). Fork length and body weight of the MC-86 group were slightly larger than those of the MJ-86 group, though there was no statistical difference between the two groups ( $t$-test, $p<0.01)$. The range of the length and the weight in all the catches were from 42.0 to $68.5 \mathrm{~cm}$ and from 740 to $3,300 \mathrm{~g}$, respectively.

To estimate the length of salmon forming winter marks by back-calculation, we chose 17 and 12 sample scales with definite winter marks from the MC-86 and the MJ-86 group, respectively. Rapid growth during lacustrine life was observed in both examined groups from the first winter in September 1987 to the second winter in September 1988 , but no rapid growth in the second year in the lake was observed (Fig. 5).

Table 3. Mean fork length (cm, $\pm \mathrm{SD}$ ) and mean body weight $(\mathrm{g}, \pm \mathrm{SD})$ of masu salmon spawners returned to the $\mathbf{R}$. Claro in Lake General Carrera in 1989

\begin{tabular}{|c|c|c|c|c|c|c|}
\hline \multirow{2}{*}{$\begin{array}{l}\text { Stock } \\
\text { group }\end{array}$} & \multicolumn{3}{|c|}{ Mean fork length $\pm S D(\mathrm{~cm})$} & \multicolumn{3}{|c|}{ Mean body weight $\pm \mathrm{SD}(\mathrm{g})$} \\
\hline & Female & Male & Total & Female & Male & Total \\
\hline $\mathrm{MC}-86^{* 1}$ & $56.8 \pm 3.9$ & $57.4 \pm 3.5$ & $57.2 \pm 3.7$ & $1,750 \pm 506$ & $1,800 \pm 435$ & $1,777 \pm 429$ \\
\hline MJ-86*2 & $55.5 \pm 4.4$ & $55.1 \pm 4.3$ & $55.2 \pm 4.3$ & $1,571 \pm 484$ & $1,604 \pm 392$ & $1,592 \pm 424$ \\
\hline Total & & & $56.3 \pm 4.1$ & & & $1,715 \pm 437$ \\
\hline
\end{tabular}




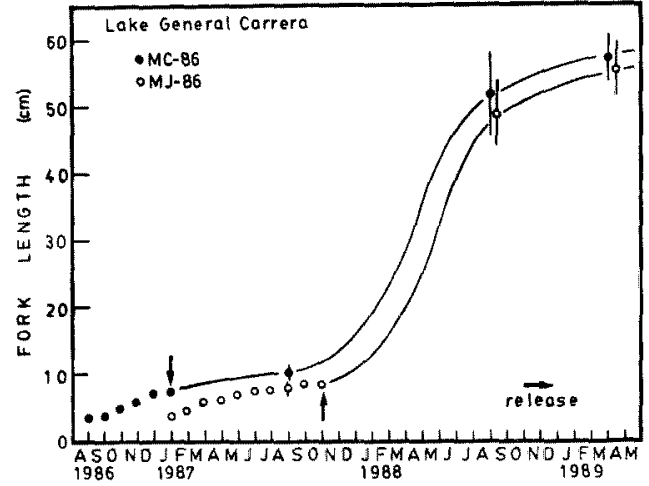

Fig. 5. Growth curve of masu salmon in each stock group (MC-86 and MJ-86) in Lake General Carrera. Arrow indicates release time of each stock parr. Fork length data before release were from pond culture records at Dr. Shiraishi's Hatchery. Fork lengths in early September 1987 and 1988, as the first and second winters, respectively, were estimated by backcalculation on a scale radius. Bars indicate SD. The curves are drawn freehand.

\section{Discussion}

\section{Release and Return}

We released two groups, of different release numbers, of masu salmon parr in 1987 (Table 1). We did not make this trial with the intention of comparing the returning habits of either of the stocks, but this suggested that though the stocks were released in different seasons and in different sizes, they returned at the same return rate (nearly $1 \%$ ) and at nearly the same size.

There are few reports about the return rate of salmon. Mayama et al. ${ }^{\text {") }}$ reported that the rate could be brought above $10 \%$ by smolt release in the Sea of Japan. According to Tanaka, ${ }^{10}$ ) the rate could be brought to $15 \%$ by smolt release. On the other hand, Kataoka et al. ${ }^{21)}$ estimated the return rate at $0.465 \%\left(2^{+}\right.$age fish $)$and $0.730 \%$ $\left(1^{+}\right.$to $4^{+}$age fish) by parr release of masu salmon in Okutadami lake. The return rate of smolt release is obviously higher than that of parr release.

Our return rate (about $1 \%$ in $2^{+}$age fish) by parr release into Lake General Carrera was higher than that in Okutadami lake $(0.465 \%$ on $2^{+}$old fish and $0.730 \%$ in $1^{+}$to $4^{+}$age fish). Since another stoch of the salmon, which must still be migrating in the lake, may return after 1990 as $3^{+}$age fish, we expect that the return

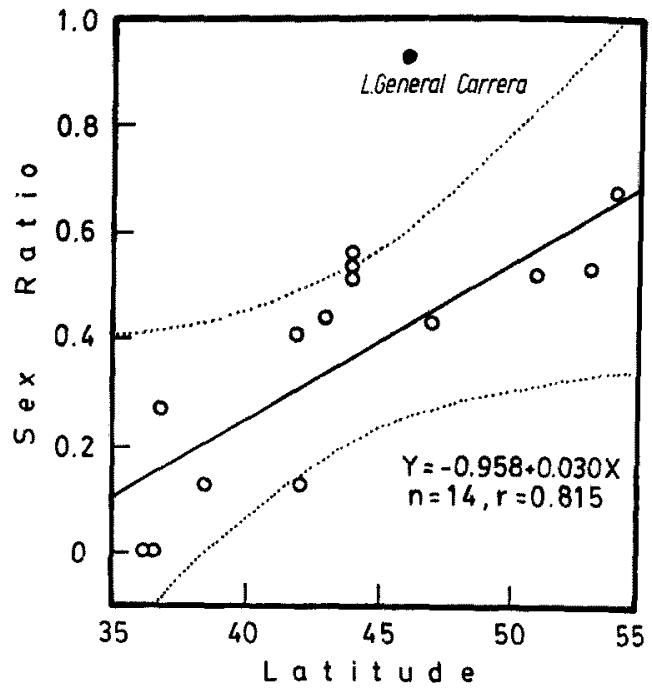

Fig. 6. Relationship between sex ratio (male numbers per female numbers) of returned masu salmon spawners in the Far East, and the latitude of the returns. Dotted line indicates $95 \%$ confidence limit. Data on the sex ratio are cited from Ono, ${ }^{26)}$ Semko, 27) Krykhtin, ${ }^{28)}$ Tana$\mathrm{ka}^{12)}$ Kato, ${ }^{28)}$ Gritsenko, ${ }^{30)}$ Honda et al.,20) Machidori and Kato, ${ }^{13)}$ Kawamura, ${ }^{31}$ and Tsygir and Ivanko. ${ }^{32)}$

rate for all the year classes will be over $1 \%$. While some spawners might migrate to other streams and rivers, we suppose that most of the masu spawners of the 1989 year class will probably return to the River Claro, because we were never able to catch any masu spawners in the neighboring streams ( $\mathbf{R}$. Largo, R. Lechoso, or R. Zanjon Feo) or in other river systems (R. Murta, R. Tranquilo, or R. Engano), which are located on the north side of the lake (Fig. 1).

\section{Sex Ratio}

Masu salmon has two life types: the sea or lake migrating type and the stream-resident type. Male salmon are usually inclined to be of the stream-resident type, staying in streams for their whole life. The appearance rate of streamresident males must affect the sex ratio both of juveniles migrating downstream and of spawners returning. It is well known that the ratio varies according to localities. ${ }^{12,13)}$ A significant relationship $(r=0.815, n=14)$ between the sex ratio of returning spawners and the latitude of the home river in the Far East was observed (Fig. 6).

The sex ratio of spawners in the Rive Claro was 
observed to be nearly 1.0. This means that few river-resident males have appeared in the river. Thus, male fish probably migrated to the lake at the same proportion of release numbers as did females. The sex ratio observed was obviously higher than that predicted by the former relationship (Fig. 6). The high proportion of male spawner numbers might have contributed to the higher return rate. We considered that it may be a severe environment $(e . g$. lower temperature or less food) in the Patagonian river of the Southern Hemisphere for the salmon parr to maintain a streamresident population than that in the same latitude of the Northern Hemisphere. In the lake, however, the masu salmon seemed to adapt to the new environment.

\section{Growth}

The mean fork lengths of female MC-86 and MJ-86 spawners ( 3 years old), 56.8 and $55.5 \mathrm{~cm}$, respectively, were equivalent to those of searun female spawners ( 3 years old), 55 to $60 \mathrm{~cm}$, in the River Shiribetsu in Hokkaido over a tenyear study. ${ }^{142}$ However, male MC-86 and MJ-86 spawners, 57.4 and $55.1 \mathrm{~cm}$, respectively, were larger than male fish in Hokkaido, 49 to $53 \mathrm{~cm}$. These indicate that masu spawners in Lake General Carrera grew as well as ocean stock in Japan, and also that the environmental condition of the lake was favorable for the salmon.

We estimated the fork length in each overwintering period from the fish which had only definite winter marks on theie scales. This treatment may not represent random sampling for the length estimate, and the growth curve examined may not represent that for all spawners, since there was a possibility that the fish which had definite winter marks on their scales had different growth modes during the first and second year in the lake from other fish without definite winter marks.

No clear size difference was observed between MC-86 and MJ-86 spawners captured in the River Claro, in spite of the fact that there was an apparent size difference between MC-86 and MJ-86 fry (Fig. 5). We considered that the initial size difference might be cancelled during the lacustrine life.

\section{Introduction and Stock Establishment Masu salmon is indigenous to the Asian Pacific}

area and has rarely been transplanted to other areas. Salmon eggs were introduced into North American lakes as a trial for a new fishery resource from the $1960 \mathrm{~s}$ to the $1970 \mathrm{s.}^{15,163}$ Salmon introduction has also been tried in Chilean Patagonia since 1973. Trials over a number of years ${ }^{5,17)}$ resulted in the first spawning run from Lake General Carrera in 1989. These results made a big step forward in establishing a selfsupporting population, though some problems still exist.

First, interspecific competition for food may occur with other salmonids and brown or rainbow trout which have already established themselves as exotic fish in the lake. The same food items, small fish like "pejerrey Odonthestes", were observed in the stomach contents of both types of trout in the lake.*8 The masu salmon in the lake probably also fed on small fish because of its carnivorous habit in lakes. ${ }^{18-21)}$ It is obvious that competition for food amongst the salmonid community may occur in the lake. At present, however, the remarkable growth indicated that the feeding environment would be good for salmon in the lake, as compared with the growth of salmon in a small lake, Lagoon Don Poli, where intraspecific competition for food existed and a lower growth rate (about $35 \mathrm{~cm}$ in fork length after the second winter) was observed. ${ }^{7}$

Secondly, there is possible competition for spawning sites. Larkin ${ }^{22}$ suggested however that competition for food will probably occur much more frequently than competition for spawning sites, since the latter is liable to be considerably more damaging to a population than occasional and temporary competition for food. The spawning site in the River Claro is dominantly utilized by brown trout from May to July, just after the breeding of the masu salmon from March to April. Hayes ${ }^{23)}$ reported that later spawning by the rainbow trout population gives them the potential to limit the brown trout population by dislodging and destroying their eggs through redd superimposition. The early spawning masu salmon may suffer disadvantages in their reproductive success in the spawning ground. Actually, a low abundance of newly hatched salmon fry was observed in the river. We consider that continuous parr release will reduce damage by competition.

Thirdly, Le Cren ${ }^{24)}$ mentioned that physical 
factors and the limits of geographical range might limit the abundance of a freshwater fish population. Climatic factors may be important for the spawning success of masu salmon acclimatizing to Patagonian lakes. From January to March, the spawning season of salmon, it is generally drier than in other months. The yearly fluctuations of the river water level in this period have fatally affected the salmon spawning success. ${ }^{* 10}$ Fortunately, the River Claro has a relatively high water flow even in the dry season, so the spawning salmon may not be greatly affected by this factor.

In conclusion, the masu salmon will probably establish a self-supporting population, judging from its adaptability to the lake system. We should also pay attention to the effects of the masu salmon introduction on the present salmonid community, as discussed by Loftus and Reigier ${ }^{253}$ on salmonid communities in oligotrophic lakes. So we must ecologically and economically establish a stable community and production in the lake on the basis of releasing salmon.

\section{Acknowledgments}

We thank Mr. J. Ruiz, and other staff of Dr. Shiraishi's Hatchery for their support in this work. The data reported here were all collected under the auspices of the Japan International Cooperation Agency (JICA), Instituto de Fomento Pesquero (IFOP), and Servicio Nacional de Pesca (SERNAP), We are indebted to Drs. S. Machidori and S. Shirahata, members of The Project Support Committee, for their critical suggestions. Finally, Mr. S. Lewis, Wildlife Warden, Neuquen Province, corrected the manuscript, for which we express our sincere thanks.

\section{References}

1) W. B. Scott and E. J, Crossman: Freshwater Fishes of Canada, Bull. 184, Fish. Res. Bd. Canada, Ottawa, 1973, pp. 138-229.

2) F, A. Davidson and S. J. Hutchinson: The geographical distribution and environmental limitations of the Pacific salmon (genus Oncorhynchus), Bull. Bureau Fish., 26, 667692 (1983).

3) I. Villa P., E. Zeiss C., and H. Gibson: Prospecciones de sistemas hidrograficos para la introduccion del "Salmon" en Chile, Biol. Pesq. Citile, 10, 61-73 (1900).

4) T. Joyner: Salmon ranching in South America, in "Salmon Ranching" (ed. by J. E. Therpe), Academic Press, London, 1979, pp. 261-276.

5) A. Nagasawa and P. Aguilera M.: Transportation and rearing trials with Japanese cherry salmon (Oneorhynchus nasou), 1972-1973. Introduc, Aysen Chile Pac. Salmon, 1 , 1-21 (1974).

6) S. Shimura, E. Cardenas, G., and A. Nagasawa: Review of ecological researchers on Pacific salmon introduced into the Aysen Region, southern Chile, Introduc. Aysen Chile Pac. Salmon, 17, 1-66 (1986).

7) M. Sakai, R. Aguirebena B., and A. Nagasawa: Growth analysis by scale reading of cherry salmon (Oncorhynchus masou) stocked in " closed-system lake "Lagoon Don Poli", southern Chile. Introduc. Aysen Chile Pac. Salmon, 18, 1-26 (1987).

8) I. N. P. F. C.: Proceeding of the Annual Meeting, 1957, pp. 70-73.

9) H. Mayama, K. Okuma, and T. Nomura: Adult return of marked masu salmon, Oncorhynchus masou, from smolts released into the Shiribetsu river in the spring of 1981 , Marine Ranch. Program Progress Rep. Masu Salmon, 3, 139-146 (1983).

10) T. Tanaka: Enhancement of masu salmon, in "Propagation of Masu Salmon", Hokkaido Fish Hatchery, 1984, pp. 51-57. (in Japanese)*11

11) T, Kataoka, N. Honda, and A. Suzuki: Studies on the reproduction of landlocked masu salmon, Oncorphynchus masou, in the Okutadami reservoir-VI. Resource amount of salmonids. Sci. Rep. Nitgata Inland Fish. Sta., 11, 1-13 (1984).

12) S. Tanaka: Salmon of the North Pacific Ocean-part IX. Coho, chinook, masu salmon in offshore waters. 3. A review of the biological information on masu salmon (Oncorhynchus masou). Int. North Pac. Fish. Comm. Bull, 16, $75-135$ (1965).

13) S. Machidori and F. Kato: Spawning populations and marine life of masu salmon (Oncorhynchus masou). Int. North Pac. Fish. Comm. Bull., 43, 1-138 (1984).

14) K. Okuma: Sex ratio, age composition, and fork length of masu salmon (Oncorhynchus masou), of the Shiribetsu river, Hokkaido, Japan. Sci. Rep. Hokkaido Salmon Hatchery, 42, $37-47$ (1988).

15) W. J. Christie: Introduction of the cherry salmon Oncorhynchus masou in Algonquin Park, Ontario. Copeia, $70,378-379(1970)$.

16) A. Netboy: Here come the cherry salmon. Fishing World, $1977,14-28(1977)$.

17) H. Asai and G. Araya, G.: Observations on the Japanese cherry salmon (Oncorhynchus masou) release trials with notes of a homing adult in the Simpson river. Introduc. Aysen Chile Pac. Salmon, 11, 1-25 (1984).

18) M. Osanai: Ecological studies on the landlocked masu salmon, Oncorhynchus masou (Brevoort)-1. Ecological succession on the limnological conditions and feeding habit of the lakelocked form at Uryu reservoir. Sci. Rep. Hokkaido Fish Hatchery, 17, 21-29 (1962).

19) M. Osanai: On the masu salmon and pond-smelt which are expected as appropriate species to stock in artificial lake. Sakana To Tamago, 17, 7-12 (1966).

20) M. Osanai: Report from the field-the masu salmon in the lakes. Special on Freshwater Fishes; Oncorhynchus masou et $O$. rhodurus, Freshwater Fish Protection Association, 1982, pp. 92-96.

21) N. Honda, T. Kataoka, M. Hoshino, and $Y$. Seki: Studies on the reproduction of landlocked masu salmon, Oncorhy. nchus masou (Brevoort), in Okutadami reservoir-II, Bcology of landlocked masu salmon during the period of upstream migration for spawning. Scr. Rep. Nitgata Inland Fish. Sta., 9, 16-23 (1981).

22) P. A. Larkin: Interspecific competition and population control in freshwater fish. J. Fish. Res. Bd. Canada, 13, 327-342 (1956).

*10 M. Sakai and E. Estay: unpublished.

*11 Tentative translation of original title in Japanese by the authors. 
23) J. W. Hayes: Competition for spawning space between brown (Salmo trutta) and rainbow trout ( $S$. gairdneri) in a local inlet tributary, New Zealand. Can. J. Fish. Aquat. Sci., 44, 40-47 (1987).

24) E. D. LeCren: Observation on the growth of perch (Perca fiuviatilis L.) over twenty-two years with special reference to the effects of temperature and changes in population density. J. Anim. Ecol., 27, 287-334 (1958).

25) K. H. Loftus and H. Regier: Proceedings of the symposium on salmonid fish community in oligotrophic lakes (ed. by K. H. Loftus and H. Regier). J. Fish. Res. Bd. Canada, 29, $611-986$ (1972).

26) 1. Ono: The life history of masu salmon of Hokkaido. Salmon Journal, 5, 13-26 (1933).

27) R. S. Semko: Some new information on the masu saimon, (O. masov) along west Kamachatka. Zool. Journal, 37
(1956)*12

28) M. L. Krykhtin: Materials on the stream life of masu salmon. TINRO Report, 48 (1962).*12

29) M. Kato: Sex ratio, fecundity, and maturation of the masu salmon, Oncorkynchus masou (Brevoort), during marine life. Bull. Jpn. Sea. Reg. Fish. Res. Lab., 23, 55-67 (1971).

30) O. F. Gritsenko: Biology of the sima (masu salmon) and coho salmon in northern Sakhalin. VNIRO Report, 10 (1973). $* 12$

31) H. Kawamura: Marine life of masu salmon, in "Propagation of Masu Salmon", Hokkaido Fish Hatchery, 1984, pp. 31-50. (in Japanese)*11

32) V. V. Tsygir and V. N. Ivanko: Freshwater masu, Oncorhynchus masou, on Artemovsk reservoir (Maritime territory). Vopr. Ikhtiologii, 27, 576-583 (1987).

*12 Not directly cited. 